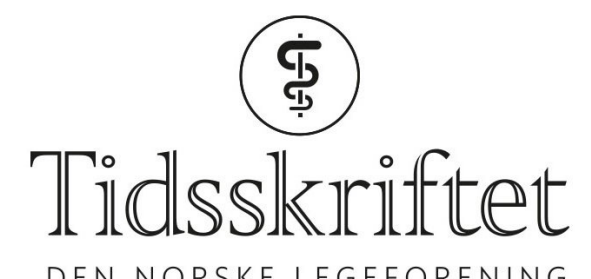

DEN NORSKE LEGEFORENING

\title{
Ordet malaria er en misforståelse
}

SPRÅKSPALTEN

\section{ERLEND HEM}

E-post: erlend.hem@medisin.uio.no

Erlend Hem er professor dr.med., fagsjef og redaktør for Tidsskriftets språkspalte.

Malaria betyr direkte oversatt 'dårlig luft'. Legen som oppdaget malariaparasitten, mente ordet var useriøst, men det lever i beste velgående.

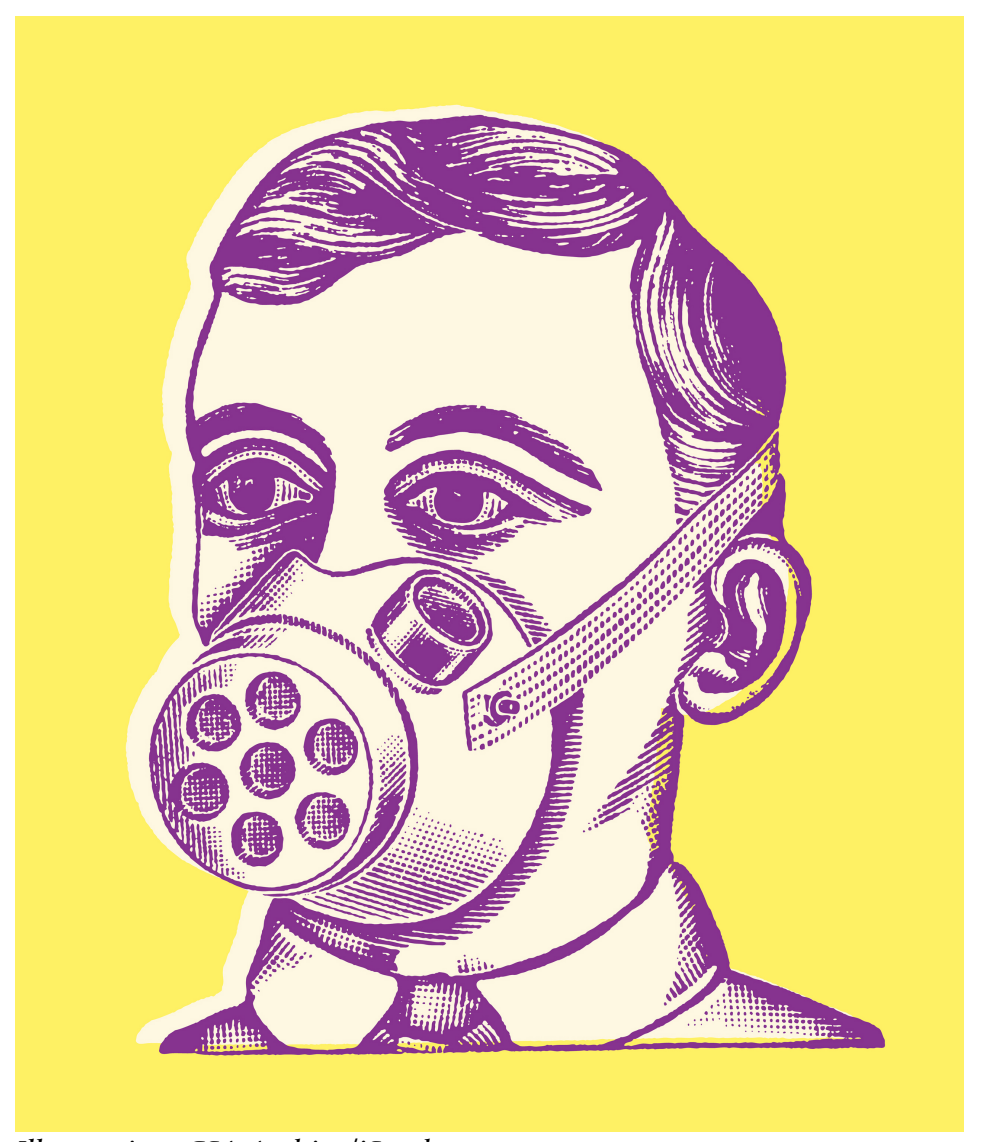

Illustrasjon: CSA-Archive/iStock

Mange anser malaria for å være verdens viktigste infeksjonssykdom. Den kan ha tatt livet av halvparten av alle mennesker som noen gang har levd (1), og dessverre er den fortsatt høyst aktuell. Det er anslått at 219 millioner mennesker fikk sykdommen i 2017 og at 435000 døde, hvorav de fleste var barn i Afrika (2).

Malaria var godt kjent allerede i oldtiden og er beskrevet blant annet i de hippokratiske skriftene (3). Det var imidlertid først i 1740 at ordet malaria første gang ble brukt på engelsk 
(4). Politikeren og forfatteren Horace Walpole (1717-97) skrev i et brev om en sykdom som kom til Roma hver sommer og drepte folk: «A horrid thing called the mal'aria, that comes to Rome every summer and kills one» (4).

Ordet malaria kommer av italiensk mala aria 'dårlig luft'. Vi kjenner igjen mala, fra latin malus 'ond, dårlig', som i mala praxis 'dårlig medisinsk praksis'. Aria er samme ord som det engelske air, som har med luft å gjøre (4).

I tidligere tider trodde folk at sykdommen kom fra den dårlige luften over myr- og sumpområder. Det var i tråd med teorien om miasmer, som innebar at sykdomssmitte ble overført gjennom luften. Miasma på gresk betyr 'forurensning' (5). Det var først i 1880 at den franske legen Charles Laveran (1845-1922) oppdaget smittestoffet i blodet, en oppdagelse han ble tildelt nobelprisen for i 1907 .

I sørlige deler av Norden var det fram til slutten av 18oo-tallet ikke uvanlig med små, lokale malariautbrudd i brakkvannsområder (6). I Norge var særlig områder rundt Oslofjorden rammet, og sykdommen gikk under en rekke navn, for eksempel klimafeber, klimatfeber, koldfeber, sumpfeber og tropefeber. Det var den intermitterende temperaturstigningen folk festet seg ved, og dermed oppsto uttrykkene tredjedagsfeber (tertianfeber) og fjerdedagsfeber (kvartanfeber).

Dr. Laveran skal ha mislikt navnet malaria, som han oppfattet som uvitenskapelig og overtroisk. Han foretrakk ordet paludisme, fra latin palus 'myr, sump', som er blitt den franske betegnelsen på sykdommen (7). Laveran hadde selvsagt rett i at navnet malaria bunner i en misforståelse. Likevel er det malaria som fortsatt brukes som navn på sykdommen over store deler av verden. Det er et godt eksempel på at gamle og feilaktige navn fortsatt kan fungere i en ny tid. Det er mange andre eksempler også, blant annet influensa. Det stammer fra et ord som opprinnelig hang sammen med at middelalderens astrologer mente at det var en væske som fløt ned fra stjernene og påvirket menneskene (8). Ingen tror lenger at malaria kommer av dårlig luft eller at influensa skyldes påvirkning fra stjernene, men vi klarer oss bra med disse ordene likevel.

\section{LITTERATUR:}

1. Whitfield J. Portrait of a serial killer. Nature 2002. doi:10.1038/newso21001-6. https://www.nature.com/news/2002/021001/full/newso21001-6.html Lest 21.9.2019.

2. Verdens helseorganisasjon. Malaria. https://www.who.int/news-room/fact-sheets/detail/malaria Lest 21.9.2019.

3. Hempelmann E, Krafts K. Bad air, amulets and mosquitoes: 2,0oo years of changing perspectives on malaria. Malar J 2013; 12: 232. [PubMed][CrossRef]

4. Malaria. I: Oxford English Dictionary. www.oed.com/view/Entry/112765 Lest 22.10.2018.

5. Larsen Ø. Miasme. I: Store norske leksikon. https://snl.no/miasme Lest 21.9.2019.

6. Folkehelseinstituttet. Smittevernveilederen. Malaria - veileder for helsepersonell. https://www.fhi.no/nettpub/smittevernveilederen/sykdommer-a-a/malaria-veileder-forhelsepersone/ Lest 22.10.2018.

7. Bruce-Chwatt LJ. Alphonse Laveran's discovery 100 years ago and today's global fight against malaria. J R Soc Med 1981; 74: 531-6. [PubMed][CrossRef]

8. Hem E. Influenza, krimfarang and A(H1N1)pdmog. Tidsskr Nor Legeforen 2012; 132: 321. [PubMed][CrossRef] 